\title{
A Study on Constructivist Teaching Approach in Mathematics Class Room
}

\section{Syeda Khaja Mohsina Banu" ${ }^{* 1}$ Prof. Siddiqui Mohd Mahmood ${ }^{2}$}

${ }^{1}$ Ph.D. Scholar, Department of Education and Training, Maulana Azad National Urdu University, Hyderabad, Telangana, India

2Professor, Department of Education and Training, Maulana Azad National Urdu University, Hyderabad, Telangana, India

\section{ABSTRACT}

Constructivism is an epistemology, or a theory of Knowledge construction, a philosophy of learning, used to explain how people know what they know. Its promoters include Piaget, Vygotsky and later-day philosopher Glasersfeld. The constructivist philosophy has been adopted in teaching of mathematics by many enthusiastic teachers in many countries. Constructivist approach learning is an interaction between the learner and learning environment. During this interaction, prior knowledge is used as the basis to interpret and construct new understanding. In other words, learning occurs if a student can construct his/her knowledge and apply or generalize its meaning to new situations, the constructivist approach opens new opportunities for learners as well as challenges for the teachers trying to implement it. In a learner centred situation, the constructivist teacher becomes one of many resources a student may learn from, and not the primary source of information, the teacher act as a facilitator, co-learner, democratic leader and a diagnostician. Researches have established that constructivist teaching approach in mathematics have been much more successful than the traditional methods. In the present paper the author has identified some of the most important reasons for lack of success of constructivist strategy, especially in developing countries.

Keywords : Constructivist Teaching Method, Transmission Teaching Method, Achievement in Mathematics.

\section{INTRODUCTION}

The basic idea of constructivism is that the learner must construct knowledge; the teacher cannot supply it (Bringuier, 1980).The idea of constructivism is not new, the glimpse of constructivism also seem in the work of Piaget and Bruner and Vygotsky .The constructivist paradigm as advocated by Piaget (1960/1981) (cited in Joan .S, 1980) and Bruner (1990) (cited in Joan .S, 1980) stresses that whatever gets in to the mind has to be constructed by the individual through knowledge discovery. Its emphasis is on how a student constructs knowledge. In other words, this theory holds the view that learning is an active process in which learners construct new ideas or concepts based upon their current or past knowledge. Constructivism is an approach in which the learner is building an internal illustration of knowledge, a personal interpretation. Sood (2008) also recommends that "learning science as a constructivist conceptual change process."

According to Simpsons (1993) (cited in Joan.S, 1980), constructivism is an approach in which the learner is building an internal illustration of knowledge, a personal interpretation. Constructivism emphasizes 
the careful study of the processes by which children create and develop their ideas. According to constructivism approach learning is an interaction between the learner and the learning environment. In other words, learning occurs if a student can construct his or her own knowledge and apply or generalize its meaning to new situations.

As people solve problems and discover the consequences of their actions through reflecting on past and immediate experiences, they construct their own understanding.

Constructivism is the theory that says learners construct knowledge rather than just passively take in information. Students' previous knowledge and their active participation in problem solving and critical thinking all play a crucial part in the construction of knowledge. One of the most important goals of constructivism is to develop students' critical thinking skills, which is possible only in a conducive learning environment in the class. The teacher may have to improvise the sequence of activities, depending on the needs of the students. Such flexibility is said to be a valuable quality of a positive learning environment (Shazli, 2019).

\subsection{Objectives of The Present Study}

The following are the objectives of the present study:

1. To explain the concept of Constructivism.

2. To identify important characteristics of Constructivist teaching having relevance in Mathematics classrooms, and to know the related pedagogies which can be usefully applied in Mathematics teaching?

3. To find how far constructivist strategies have been successfully employed in mathematics classroom both in India and abroad.

4. To explain role of teacher in constructivist classroom.

5. To explain evaluation in constructivist classroom.
6. To present a few suggestions to implement constructivist teaching approach in mathematics classroom.

\subsection{Methodology of The Present Study}

This is a descriptive study of constructivist approach and its implementation in schools. Keeping in view of availability of the resources and the feasibility of the present research study, the author conducted his research studies on the basis of secondary sources of data. Secondary data has been collected from several books, research papers published in standard and prestigious Journals etc.

\subsection{Concept of Constructivism}

Constructivism as a new theory of learning, gaining popularity in the education system all-over the world. It is contrary to traditional method of teaching and includes the learner centred education system.

Constructivism is a view of learning based on the belief that knowledge is not a thing that can be simply given by the teacher inside the class room to the students on their desks. Rather, it keeps the students active in the class room and engages in knowledge construction process.

\subsection{Characteristics of Constructivist Teaching}

Main aims of using constructivist teaching approach is that students learn how to learn by giving them the training to take initiative for their own learning experiences. The main characteristics of a constructivist teaching/class room are as follows:

$>$ Students are actively involved

$>$ The environment is democratic

$>$ The activities are interactive and studentcentered.

Aims and objectives are derived by the student or in negotiation with the teacher or system. 
The role of teacher in constructivist approach is as guide, monitors, coaches, tutors and facilitators.

$>$ Activities, opportunities, tools and environments are provided to encourage meta-cognition, selfanalysis-regulation, self-reflection and selfawareness.

$>$ Knowledge construction and not reproduction is emphasized.

> This construction takes place in an individual context and through social negotiation, collaboration and experiences.

$>$ The students' previous knowledge construction, beliefs and attitudes are considered in the knowledge construction process.

$>$ Errors provide the opportunity for insight into students' previous knowledge construction.

$>$ Exploration is a flavored approach in order to encourage students to seek knowledge independently and to manage the pursuit of their goals.

$>$ Students are provided with the opportunity for apprenticeship in which there is an increasing complexity of tasks, skills and knowledge acquisition.

> Collaborative and cooperative learning are favored in order to expose the learner to alternative viewpoints.

> Scaffolding is facilitated to help students perform just beyond the limits of their ability.

$>$ Assessment is authentic and interwoven with teaching.

\subsection{Constructivism In Mathematics Classroom}

Mathematics has the ability to confuse, scare and frustrate learners of all ages. If a child has negative experience in mathematics, that experience would affect his / her achievement as well as attitude towards mathematics during adulthood (Dr. Femila Pangat, 2017). The obvious question is whether students' failure to learn mathematics can be ascribed to problems of curriculum, problem of teaching, or the student, or perhaps the combination of these (Dr. FemilaPangat, 2017). There are many possible reasons for students failing in mathematics. But most of the reasons are related to mathematics curriculum and methods of teaching rather than the students' lack of ability to learn. Airasian and Walsh (1997) argue that the existing mode of teaching of mathematics in schools has not fulfilled the needs of the vast majority of our students, and that not enough instructional stress put on the higher order skills. Traditional method of teaching makes the students memorize information, conduct organized experiments, and perform mathematical calculations using a specific algorithm which makes them submissive and rule-bound. The traditional teacher as information giver and the textbook guided classroom have failed to bring about the desired outcomes of producing thinking students (Jagdeep, 2017).

A much proclaim alternative is to change the focus of the classroom from teacher-centered to student-centred using a Constructivist Approach. Constructivist teaching practices in Mathematics classrooms are intended to produce much more challenging instruction for students and thus, produce improved meaningful learning. This method has led the students to participate actively in the mathematics classroom by explaining their mathematical reasoning to each other and constructing their own understanding of mathematical concepts.

Constructivist teaching approach is a strategy that can enable all the students to construct valid knowledge and also enable them to transmit it in different contexts. Learning in the constructivist environment contributes to intellectual, social and psychological development of learners unlike other methods of instruction. Constructivist teaching in Mathematics believes that student can construct 
knowledge by active participation rather than acquiring knowledge by watching teachers' demonstration in the classroom and, to learn to speak, think and act mathematically participating in Mathematical discussion and solving new or unfamiliar problems (Richards, 1991).

\subsection{Role of Teacher In Constructivist Classroom}

Constructivist teacher is a dispenser of knowledge, a guide, facilitator and co-explorer who encourages learners to question, challenge and formulate their own ideas opinion and conclusions. Teacher as a facilitator sets up problems and monitors learner's exploration guides the direction of learner and promote new pattern of thinking. Teacher recognizes how students use their own experiences, prior knowledge and perceptions, as well as their physical and interpersonal environments to construct knowledge and meaning. The aim of the constructivist teacher is to produce a democratic classroom environment that provides meaningful learning experiences for autonomous learners. Characteristics of a constructivist teacher are as follows.

(Brooks \& Brooks, 1993 and Yager, 1991).

1. Constructivist Teachers accept and encourage the self-administration and entrepreneurship of students.

2. Constructivist Teachers respect students' opinions and they encourage students to think independently.

3. Constructivist Teachers help students for having intellectual identity.

4. Constructivist Teachers ask students open ended questions and provide the sufficient time for them to answer.

5. Constructivist teachers encourage students to go beyond giving simple answers founded on facts.
6. Constructivist Teachers encourage high-level of thinking of students. Students are encouraged to summarize the concepts by analyzing, estimating and verifying to establish relationships besides defending their opinions.

7. Constructivist Teachers Promote students leadership, collaboration and collection of information and taking actions as a result of the learning process.

8. Constructivist teacher encourage the use of alternative sources of information like written materials and experts.

9. Constructivist teacher Seek out student ideas before presenting teacher ideas or before studying ideas from textbooks or other sources.

10. Constructivist teacher Encourage students to challenge each other's conceptualizations and ideas.

11. Constructivist teacher Encourage self-analysis, collection of real evidence to support ideas and reformulation of ideas in light of new knowledge.

12. Constructivist teacher Present tasks with realworld application so that students can contextualize their knowledge easily.

13. Constructivist teacher Give assistance so that students are able to consolidate their established understanding with their new learning.

14. Constructivist teacher Provide scaffolds to bridge the gap between what learners know and what they are being presented with.

15. Constructivist teacher serves as one of many resources for students, not necessarily the primary source of information.

The primary responsibility of a constructivist teacher is to create and maintain a collaborative problem-solving environment, where students are 
allowed to construct their own knowledge and the teacher acts as a facilitator, guide and co-explorer.

\subsection{Collaboration and Scaffolding In A Constructivist Classroom}

Students are encouraged to work together to discuss a "controversy" to ask each other questions. Students should be allowed for 'reciprocal 'learning. A less skilled child may be 'tutored' by a more skilled child. Such cooperative learning and group discussion definitely create great interest and motivation among the students. Few experts have recommended the organization of the "jigsaw" technique. In a jigsaw technique, students are divided into groups and one member from each group is taught new skills. This "expert" member then goes back to his original group and teaches the new skills to his group members (Shazli, 2017). A particularly weak student may be given greater help and support by his teachers or even by co-learners. This level of support may be changed, increased, or decreased, as needed by that student. This is called "scaffolding".

\subsection{Evaluation in A Constructivist Classroom}

The traditional system of evaluation and examination has remains unchanged in schools. The summative approach - an examination at the end of school year-promotes accumulation of knowledge. Most of the students cram their notes and resort to rote learning. Such a procedure sends a very wrong message to the students---which learning means simply reproduce lessons without understanding it. In a constructivist set up, the traditional assessment system will defeat the very purpose of teaching. Learning means —understanding\| and which implies that one is able to explain what one knows. In a constructivist approach, assessment is interwoven with teaching. Students' activities, their work and portfolios, are all taken into account. It is their understanding and - knowledgell that is assessed.

Though judgments are involved in a constructivist classroom, but these are given to community authority and negotiation rather than to the individual teacher. In addition, assessments are made using multiple authentic measures, such as observations, dialogue journals, field notes, and portfolios, as well as test scores. These authentic assessments encourage students to participate in lifelike problem-situations, which are therefore long remembered. Memorization of facts is less important than developing skills for problem-solving and lifelong learning. The real purpose of evaluation is to assist the teacher in determining how well the student is mastering the concepts. Hence students' performance should be monitored continually while the lesson is taught.

\subsection{Suggestions To Improve Constructivism In Mathematics Classroom}

1. This approach highlights the shift from teacher centered to learner-centered classroom wherein the students are given freedom to explore and discover things on their own.

2. This approach could really be very useful to the teachers in creating constructive classroom situations wherein the students are the meaning makers.

3. Constructivist approach may be introduced into the entire curriculum of all levels of educational system for enhancing quality in the educational field.

4. It is found that constructivist approach is more effective than the conventional method of teaching mathematics studies in fostering achievement in mathematics studies. As discussed earlier, social mathematics is generally conceived as a hard core and a boring subject 
mainly due to the rigid ways of presenting the subject matter. Using constructivist pedagogy can stimulate learner's thinking abilities and make them more critical and analytical towards the issues and problems of day to day life. So this approach can be practiced in the schools to facilitate meaningful learning among the students.

5. The nationalized prioritized values can be developed through certain social concepts such as democracy, equality, environment and so on by using group situations, discussion models and inquiry methods.

6. A new culture is suggested to be built in preservice teacher education to place student teachers in contexts where they can practice the innovative approaches. In other words, courses should shift from a teacher-centered approach to learner-centered approach. Since co-operative learning which has been used consistently in the class which helped in resolving issues and conflicts, related to certain social problems and values, this strategy as a part of constructivist pedagogy can be used in the classrooms.

\section{Conclusion}

In many countries, like USA, Italy, Turkey, Nigeria, Middle East, and many other countries efforts have been made to adopt constructivist philosophy in the teaching of Mathematics. It has been noted that these practices were made in primary and secondary schools. Teachers generally offer resistance to adopting the constructivist position. The reason is simple. Firstly constructivist strategy is timeconsuming. Students have to be given ample time for "reflecting", group discussion, and so on. They are slow and have little motivation or interest in learning. In fact, they do not possess the minimum level of readiness that leads to learning. Secondly, teachers are not trained in the constructivist methodology. Generally, teachers are averse to creating learning environments as it entails a "waste "of time. Pre-service teacher training should include constructivist methods. Technology has a specific role to play in a constructivist classroom. It is found that online animations, virtual labs, computer software, and sensors have increased test scores significantly. Most of the schools in India lack access to technology. Unless the government helps in a massive way, most of the schools and school teachers in India are not likely to change their ways. To conclude, it can be said that Constructivist pedagogy is a very effective means of Mathematics teaching. However, the success of this approach presupposes that the teachers should not only be well trained in a constructivist approach, but they should also be dedicated enough to follow its requirements patiently. This approach is timeconsuming and requires a lot of patience on the part of teachers and administrators. The teachers should also be trained in the use of relevant technologies.

\section{REFERENCES}

[1]. Dewey, J (1933). How we think: a restatement of the relation of reflective thinking to the educative process. Chicago: Henry Regnery.

[2]. Etuk, E.N. et al (2011). Constructivist Instructional Strategy.In Bulgarian Journal of Science and Education Policy, Vol 5, No. 1, 2011.

[3]. Gabric, K. et al. (2006). Scientists in their own classroom: the use of type II technology in the science classroom. Computers in the schools.22(3-4), 77.

[4]. Jonassen, D., Peck, K.L., Wilson, B.G. (1999). Learning with Technology: A Constructivist perspective. New Jersey; Prentice Hall. 
[5]. Lorsbach, A and Tobin, K. (2012).“Constructivism as a referent for Science Teaching".Printed in National Association for Research in Science Teaching (NARST).

[6]. Mathews, M.R. (2000). Editorial of the Monographic issue on Constructivism, Epistemology and the Learning of Science' Science \& Education, 9 (3).

[7]. Von Glasersfeld, E. (1989). Cognition, Construction of knowledge and teaching Synthesis. 80(1), 121-140.

[8]. Von Galsersfeld, E. (1990). Constructivism in education.In A Lewy (Ed.) The International Encyclopedia of curriculum. Oxford. Pergamon London: Falmer Press.

[9]. Von Glasersfeld, E (1996). Aspects of Constructivism. In C.T. Fosnot (Ed), Constructivism: Theory, Perspectives, and Practice. New York., N.Y. Teachers College Press, Columbia University.

[10]. Vygotsky, L.S. (1986). Thought and Language. Cambridge. Massachusetts. MIT Press.

[11]. Yager, R. (1999).The Constructivist Learning model, towards real reform in Science education. The Science Teacher. 58(60, 52-57.

[12]. Dr. FemilaPangat(2017).A study on effect of constructivist pedagogy on the academic achievement of secondary school students in mathematics, International Journal of Applied Research 2017; 3(3): 427-430.

[13]. JagdeepKaur(2017). Effect of Constructivist Approach on Achievement In Mathematics Of Elementary School Students. SRJIS/BIMONTHLY/DR. JAGDEEP KAUR \& RAMAN (5649-5656)

\section{Cite this Article}

Syeda Khaja Mohsina Banu, Prof. Siddiqui Mohd Mahmood, "A Study on Constructivist Teaching Approach in Mathematics Class Room", International Journal of Scientific Research in Science and Technology (IJSRST), Online ISSN : 2395-602X, Print ISSN : 2395-6011, Volume 6 Issue 2, pp. 878-884, March-April 2019. Available at doi : https://doi.org/10.32628/IJSRST2072201 Journal URL : https://ijsrst.com/IJSRST2072201 